\title{
Konstruksi Diri dan Pengelolaan Kesan pada Ruang Riil dan Ruang Virtual
}

\author{
Oleh: Benedictus A.S ${ }^{1}$
}

\begin{abstract}
The development of technology, especially in media, has affected the form of self and interaction in everyday life. In real life situation, humans actually have face to face interactions and they can see others' given and givenoff behaviors. However, when the internet becomes one of the tools for interacton with others, a different forms of self and interaction emerge. It means we are doing an interaction in the mediated world which we call as interpersonal mediated communication. In this era, we do not know exactly the kind of people we communicate with, so one of ways to know about others is from the impression they give us; which is call a front stage. In this paper I introduce how the dramaturgical concept, especially the Impression Management, from Erving Goffman can be used to describe how people interact in the virtual world.
\end{abstract}

Key Words : given and given off behavior, interpersonal mediated communication, front stage, dramaturgical, impression management

\section{Pendahuluan}

Pada sebuah acara reality show di televisi beberapa waktu yang lalu, seorang peserta ditanyakan kalau kita harus berhubungan (relasi), apakah yang akan anda lakukan untuk diri saya di pagi hari ? Peserta wanita itu menjawab " saya tidak bisa melakukan apapun untuk anda, karena hal pertama yang saya lakukan di pagi hari adalah menyalakan computer, membuka facebook dan merubah status (status updates) di facebook saya, jadi kalau anda mau makan, ya ambil sendiri saja," kata peserta wanita tersebut. Pernyataan dari peserta wanita ini menandakan suatu perkembangan luar biasa ketika manusia menggunakan internet sebagai sebuah medium untuk berkomunikasi. Artinya, perubahan dalam diri seseorang bisa membuat suatu hubungan yang sebelumnya intim, menjadi

1 Dosen Ilmu Komunikasi Universitas Pelita Harapan 
hubungan yang impersonal bahkan mengarah pada alienasi akan adanya suatu hubungan.

Banyak sudah contoh kasus yang menandakan perubahan cara berpikir, sikap dan perilaku individu ketika berinteraksi dengan orang lain melalui internet. Seorang Motivator terkenal, Mario Teguh yang menulis pernyataan bahwa perempuan yang suka dugem dan perokok tidak layak untuk dinikahi melalui saluran twitter, kemudian menarik pernyataannya bahkan menutup account twitter-nya ketika mendapatkan protes dan hujatan. Protes dan hujatan ini menandakan pergeseran pemikiran Mario Teguh di ruang riil yang selalu menempatkan posisi manusia dalam kerangka konstruktif yang positif menjadi menempatkan manusia dalam posisi yang negatif dan destruktif.

Kondisi ini memperlihatkan bahwa pikiran yang sudah ditempatkan di suatu saluran (channel) seperti di internet berbeda dengan pikiran yang ada di ruang riil. Artinya pikiran, sebagai sebuah sarana ekspektasi terhadap perilaku individu, di ruang virtual lebih minimal (karena tiadanya individu yang mengetahui siapa diri kita ketika melakukan interaksi) dibandingkan dengan ruang riil itu sendiri, karena itu di ruang virtual kesan lebih ditekankan. Sehingga salah satu sikap yang bisa dilakukan untuk memperbaiki kesan itu adalah dengan menutup account Mario Teguh MTGW. Kasus lain yang bisa kita juga bisa melihat kasus Luna Maya dengan Wartawan Infotainment, di dunia sosial nyata (real world), perselisihan tersebut tidak terlihat, namun ketika masuk ke ranah ruang virtual, maka perselisihan menjadi nyata.

Kedua kasus di atas memperlihatkan tentang kekuataan internet yang membuat diri seorang menjadi lain dibandingkan diri sebenarnya atau bahkan dikatakan bahwa terjadi perubahan dalam pengelolaan kesan, biasanya pengelolaan kesan yang terjadi di ruang virtual lebih kuat, artinya di ruang virtual pengelolaan kesan yang baik atau positif selalu ditampilkan, namun di ruang riil pengelolaan kesan ternyata lebih lemah (kesan yang ditampilkan di ruang riil tidak bisa "diputarbalikkan", karena perilaku verbal maupun non-verbal bisa terlihat secara langsung).

Seperti dikatakan oleh Erving Goffman bahwa, "ketika seorang individu hadir di hadapan seorang lainnya, mereka umumnya berusaha untuk mendapatkan informasi mengenai lawan bicaranya atau memainkan informasi tentang dirinya yang sudah mereka miliki”. Artinya, individu adalah seseorang yang selalu berkeinginan untuk mengelola kesan yang 
baik dihadapan lawan bicara dengan tujuan agar interaksi terjadi secara terus menerus. Pada kondisi inilah terbentuk konsepsi diri secara sosial yang bisa tergambar oleh lawan bicara, sehingga bisa dikatakan bahwa lawan bicara kita maupun diri kita-pun bisa memiliki ekspektasi terhadap apa yang kita pikirkan atau lakukan (Goffman, 1959:1).

\section{Interaksi dan Pembentukan Diri di Ruang Riil}

Manusia adalah seorang makhluk sosial atau dalam arti, manusia merupakan seorang mahkluk hidup yang selalu berkeinginan untuk berhubungan dengan orang lain. Hubungan manusia dengan manusia lainnya bukan dalam rangka untuk 'mengasah' instingnya atau sifat naturalnya, tetapi lebih penting adalah untuk beradaptasi dengan lingkungannya. Adaptasi manusia dengan lingkungannya inilah (sifat nurtural) membuat manusia berbeda dengan makhluk hidup lain seperti binatang. Artinya dengan manusia mampu untuk beradaptasi, maka manusia mampu untuk membuat sebuah alat yang bisa digunakan oleh dirinya untuk 'berkawan' (to socius)" dengan orang lain.

Adaptasi manusia dengan manusia lainnya untuk terus berhubungan selalu dikaitkan dengan faktor komunikasi. Dengan berkomunikasi, maka akan tercipta dan terbentuk suatu interpretasi mengenai pesan yang dikirim oleh masing-masing pihak yang pada akhirnya membentuk pemaknaan simbol yang sama satu dengan lainnya. Seperti dikatakan oleh John Stewart bahwa suatu komunikasi antar manusia ditujukan untuk mendapatkan kualitas dari komunikasi (quality of communication) yang nantinya akan berdampak pada kualitas dari hidup individu (quality of life). Hal yang dikemukakan oleh Stewart ini menggambarkan bahwa suatu komunikasi yang berhasil adalah komunikasi yang bisa membuat individu menjadi 'Seseorang' atau as a person' (artinya adalah kita membuat orang lain menjadi lebih berkualitas secara pribadi, sehingga dengan kualitas yang dihasilkan diharapkan hubungan komunikasi terus terjalin). Oleh karena itu Stewart membagi bentuk komunikasi menjadi 2 bagian, yaitu impersonal dan interpersonal (Stewart, $2006: 32-33$ ).

Menurut Stewart, impersonal adalah hubungan yang dilakukan manusia hanya berdasarkan pertukaran peran secara sosial saja, misalnya, ketika anda memperpanjang Surat Ijin Mengemudi (SIM), maka peran anda adalah seorang pembuat dan peran polisi adalah individu yang membuat SIM, sehingga setelah aktivitas yang anda lakukan selesai, maka selesai 
juga hubungan diantara anda berdua. Namun, kondisi berbeda terjadi kalau kita mencoba menggambarkan mengenai bentuk interpersonal, dimana masing-masing pihak sudah saling mengenal dan bahkan menjadi lebih intim lagi dibandingkan sebelumnya atau dapat dikatakan terjadi pertukaran kualitas kehidupan yang lebih baik yang ditandai oleh interaksi secara terus menerus.

Kualitas kehidupan yang ditandai oleh interaksi terus menerus sangat beralasan, karena menurut Altman dan Taylor memandang proses perkembangan suatu hubungan bergerak dari komunikasi superfisial atau impersonal (basa-basi, hanya permukaan saja atau non-intim) menuju komunikasi yang lebih intim atau personal. Keintiman di sini lebih dari sekedar keintiman fisik, melainkan juga intelektual, emosional dan sejauh mana mereka melakukan kegiatan bersama. Artinya suatu hubungan yang terjadi di realitas riil, bisa dilihat secara mudah bila dibandingkan dengan hubungan yang terjadi di ruang virtual (West \& Turner, 2009).

Karenanya bentukan diri dalam interaksi di ruang riil akan sangat berbeda dengan diri di ruang virtual. Diri di ruang riil bisa dikatakan interaktan bisa terlihat secara langsung atau bisa dikatakan bahwa masingmasing pihak yang berinteraksi bisa mengetahui pesan verbal dan non-verbal atau tampilan masing-masing pihak, seperti jenis kelamin, bentuk fisik, cara serta intonasi berbicara, maupun tampilan fisik lain. Sedangkan di ruang virtual masing-masing pihak tidak diketahui tampilan yang diperlihatkan, seperti dikatakan oleh Hardey, "anda mungkin suatu saat memilih untuk menjadi tinggi dan cantik; tetapi di lain kesempatan berharap menjadi seorang yang mempunyai tubuh pendek dan biasa. Hal tersebut merupakan suatu gambaran untuk melihat bagaimana merubah atribut fisik akan merubah komunikasi anda dengan orang lain" (Hardey, 2002:570). Artinya individu ketika berada di ruang virtual tidak akan diketahui atribut fisiknya. Lalu, bagaimana interaksi dan pembentukan diri di ruang riil ?

\section{Pembentukan Diri di Ruang Riil}

Diri di ruang riil selalu dikaitkan dengan proses sosiologis yang juga banyak dinyatakan oleh ahli Sosiologis, seperti Cooley, Erving Goffman, bahkan hingga G.H. Mead. Mead sebagai seorang sosiologis banyak berpikir mengenai interaksi sosial yang dapat membentuk konsepsi diri. Mead mengatakan bahwa diri (self) dibentuk melalui proses interaksi dengan orang lain. Pembentukan diri dalam proses sosial terjadi dalam 
beberapa tahap penting, yakni tahap imitasi, bermain (playing), serta tahap pertandingan (gaming). Pada ketiga proses ini dapat dikatakan bahwa diri merupakan bentukan yang bersifat individual dan sosial. Berbentuk individual bukan berarti bahwa seseorang membentuk dirinya sendiri, melainkan seseorang melakukan peniruan dari simbol yang dikirim oleh orang terdekatnya, inilah yang disebut sebagai significant others atau pada tahap pertama dikatakan individu mencoba untuk menginternalisasikan berbagai objek yang ditemuinya. Sehingga pada tahap awal ini individu tersebut mengetahui antara individu yang memegang kekuasaan dengan dirinya sendiri, karenanya tercipta pengalaman individual. Kemudian sosial dapat dikatakan bahwa seorang individu yang sudah mengetahui dan mengalami objek yang ditemuinya, sudah mulai menyadari mengenai keberadaan dirinya dengan objek lainnya dalam sebuah lingkungan. Artinya sifat sosial dari pembentukan diri merupakan hasil atau produk dari interaksi.

Oleh karena itu Mead membagi bentuk diri dalam dua bentuk yang saling berkaitan, bahkan dapat dikatakan sebagai sebuah koin dengan dua wajah, yakni I dan Me. I (aku) adalah bentuk diri yang sifatnya cair dan kreatif serta bersifat subjektif, sedangkan Me (saya) adalah bentuk diri yang sifatnya terikat dan terstruktur dan objektif. Artinya bentuk Me (Saya) adalah bentuk diri yang terbentuk dari hasil sosial dan merupakan bentuk diri yang terikat dengan aturan, nilai dan norma yang berlaku dalam masyarakat. Kedua bentuk diri ini terus berinteraksi ketika terjadi interaksi sehingga hasil diri sesungguhnya adalah bentuk diri sebagai hasil dari produksi sosial. Karenanya Mead mengatakan bahwa konsep diri adalah suatu gambaran atau citra mengenai siapa dan apa diri kita sebenarnya yang terus berubah dan tidak tetap dari setiap interaksi yang kita lakukan.

Diri yang terus berubah merupakan diri yang selalu menyesuaikan atau beradaptasi dengan harapan orang lain sebagai lawan interaksi kita. Sehingga dapat dipahami bahwa diri merupakan bentukan hasil respon orang lain terhadap kita, contohnya ketika kita kecil maka orang tua kita mengetahui kita haus atau lapar adalah dari reaksi yang kita berikan pada mereka, misalnya dengan menangis. Namun, setelah kita semakin tumbuh, maka kita semakin mengetahui bukan saja perilaku individu lawan bicara kita, juga kita makin mengetahui peran yang ia mainkan, sehingga kita mampu untuk mengambil peran dari individu lawan bicara kita.

Konsepsi diri seperti diungkapkan oleh Mead ini juga disadari oleh Cooley yang memberikan pemikiran mengenai looking glass self sebagai 
usaha pembentukan diri. Cooley membuat pemikiran mengenai looking glass self dalam 3 komponen, yaitu pertama, bahwa individu belajar untuk mengetahui mengenai dirinya pada setiap situasi dengan membayangkan dirinya sendiri melalui refleksi terhadap tampilan sosialnya artinya individu membayangkan dirinya ketika orang lain melihat dirinya, kedua, individu membayangkan apa yang orang lain pikirkan mengenai dirinya, ketiga, dan yang paling penting adalah individu mengalami reaksi emosional yang berhubungan dengan penilaian orang lain, artinya kalau orang lain menganggap penilain terhadap individu positif, maka pengaruhnya positif, begitu pula sebaliknya.

\section{Pengelolaan Kesan di Ruang Riil}

Dalam pemikiran Goffman diri merupakan bentukan dari pengelolaan kesan yang dilakukan individu ketika berinteraksi dengan individu lainnya. Artinya bisa dikatakan bahwa diri bukan merupakan situasi yang tetap, tetapi berubah dimana pada tiap interaksi masing-masing pihak harus mendefinisikan situasi yang terjadi sesuai dengan peran yang dimainkannya. Karena itu dapat dikatakan bahwa aktivitas mendefinisikan situasi membuat tiap individu sebagai bentuk diri untuk selalu berperan aktif dalam proses interaksi alam kehidupannya sehari-hari.

Diri sebagai sebuah gambaran dalam proses interaksi adalah sebuah kesadaran dimana individu bahwa dirinya sedang melakukan hubungan sosial, baik dengan individu atau kelompok lain. Ketika manusia sadar sedang melakukan interaksi, maka segala macam isyarat dan tanda yang ditampilkan-pun merupakan suatu bentukan yang sudah dipikirkan oleh individu tersebut. Individu mengetahui tampilan yang akan diberikan kepada individu lainnya atau dalam pemikiran Goffman disebut sebagai Pengelolaan Kesan (Impression Management) yang berarti juga sebagai permainan peran seperti dikatakan oleh Mulyana (2002:108-109) sebagai ekspektasi yang di definisikan secara social dan dimainkan oleh seseorang dalam suatu situasi untuk memberikan citra tertentu kepada khlayak yang hadir di hadapannya. Karena itu menurut Goffman, permainan peran atau pengelolaan kesan bersifat jangka pendek dan akan terus berubah sesuai dengan kondisi interaksi yang terjadi.

Pengelolaan Kesan adalah cara dimana individu berusaha untuk merencanakan, mengadopsi, serta proses mengambil citra diri dari individu lain dalam suatu interaksi. Pengelolaan Kesan seperti inilah yang dikatakan 
oleh Goffman (1959:17) sebagai "the benefit of other people"; artinya bahwa kita berinteraksi dengan simbol yang kita ambil dari reaksi orang lain sehingga tampilan kita sesuai dengan persepsi orang tersebut atau dalam konsep Goffman dikatakan sebagai ekspresi dan impresi. ${ }^{2}$

Pemikiran Goffmanjuga secarasederhana mengatakan bahwapengelolaan kesan di ruang riil adalah cara seorang individu yang dianalogikan sebagai seorang aktor yang sedang bermain drama, maka individu tersebut berusaha untuk mengembangkan atau memainkan peran yang diberikan kepadanya. Permainan peran seorang individu tentu saja akan lebih menyakinkan lagi apabila di dukung oleh sebuah persiapan, antara lain persiapan kelengkapan seperti setting, penggunaan kata serta tindakan-tindakan nonverbal. Melalui persiapan-persiapan itulah individu dimungkinkan untuk mengelola kesan terhadap dirinya dan mampu untuk merencanakan suatu bentuk sikap dan tingkah laku yang sesuai dengan ekspektasi orang lain.

Sebagai sebuah drama, karenanya persiapan untuk sebuah drama sangat penting untuk dilakukan. Pada sebuah komunikasi di ruang riil, maka ekspektasi terhadap orang lain dapat diukur, misalnya melalui suatu jarak yang diinginkan untuk terjadi. Seperti dikatakan Edward T Hall (dalam West\&Turner, 200204:137) melalui pemikiran proksemiknya bahwa ketika individu berinteraksi, maka ada jarak-jarak yang diperlukan dalam interaksi tersebut, yaitu jarak intim (0-18 inci), jarak personal (18 inci-4 kaki), jarak sosial (4-12 kaki), dan terakhir jarak publik (di atas 12 kaki). Jarak-jarak ini bukan merupakan ukuran baku pada setiap budaya atau bangsa, tetapi dengan ukuran ini setidaknya individu mengetahui jarak yang nyaman dan diperbolehkan boleh terjadinya suatu interaksi. Artinya ketika terjadi interaksi apabila terjadi pelanggaran terhadap jarak yang diinginkan, maka ada harapan yang tidak terpenuhi, karenanya bisa terjadi interaksi tidak nyaman dan menimbulkan keinginan untuk menghentikan komunikasi.

2 Goffman berpikir bahwa dalam sebuah interaksi tentunya ada suatu aksi dan reaksi. Pemikiran Goffman ini akhirnya merujuk pada konsep Dramaturgi, seperti dikatakan oleh Sukidin (2002), yaitu sebuah pendekatan yang menggunakan bahasa dan khayalan teater untuk menggambarkan fakta subjektif dan objektif dari realitas sosia. Pemikiran Goffman ini yang pada akhirnya membawa Goffman untuk membedakan dua macam pernyataan : 1) the expression that he gives atau bisa dikatakan sebagai ekspresi, 2) the expression that he gives off atau dapat dikatakan sebagai impresi. Ekspresi merujuk pada cara berkomunikasi secara tradisional, yaitu individu memberikan suatu informasi; sedangkan impresi adalah suatu tindakan yang diberikan orang dan juga suatu harapan bahwa tindakannya sesuai dengan alasan-alasan tertentu daripada hanya memberikan informasi. Jadi dapat dikatakan bahwa terjadi perbedaan antara pemberian informasi dengan tindakan balasan. 
Jarak ini membuat suatu interaksi menjadi bisa diprediksi, namun selain jarak menurut pemikiran Goffman dalam teori Dramaturgis, maka bagaimana melakukan pengelolaan panggung depan (front stage) menjadi lebih penting. Panggung depan adalah suatu wilayah aktor berusaha untuk mendefinisikan situasi sehingga memenuhi harapan dari khalayak. Pada panggung depan ini, Goffman mengatakan bahwa terdapat 2 faktor penting yaitu personal front (performance dan manner) serta setting (lingkungan atau kondisi tempat terjadinya interaksi).

Indikator dari personal front menggambarkan bahwa citra dari masing-masing individu yang berkomunikasi bisa terlihat langsung. Seperti dikatakan oleh Goffman (1999:1) bahwa ketika seorang individu masuk dalam penglihatan orang lain, mereka biasanya berusaha untuk mendapatkan informasi mengenai dirinya atau memainkan informasi mengenai dirinya yang sudah mereka miliki. Artinya 'lawan bicara' kita seringkali tertarik pada informasi mengenai status sosial ekonomi, sikap diri saya ke orang lain, konsepsi mengenai dirinya, kompetensinya, bahkan seperti dikatakan oleh Goffman, kepercayaan terhadap dirinya.

\section{Interaksi dan Pembentukan Diri di Ruang Virtual}

Turkle dalam tulisannya di buku Life Beyond The Screen mengatakan bahwa ketika kita berada di ruang virtual, tidak ada orang yang tahu (kalau) kita adalah anjing (bersifat anonymous). Pernyataan satir ini memperlihatkan bagaimana luar biasanya medium internet ketika memasuki ruang interaksi antar manusia. Namun di balik itu juga, Turkle berusaha untuk membuat pembacanya untuk berefleksi bahwa diri di ruang virtual bukan lagi diri yang sifatnya tunggal dan tetap, tetapi diri bersifat multiple, dinamis dan cair.

Karena itu dapat dikatakan ketika kita berinteraksi dengan individu lain di ruang virtual, maka bentuk interaksi yang terjadi bukan lagi interaksi tatap muka, tetapi interaksi yang sifatnya hyper-interaction - atau dapat dikatakan sebagai interaksi yang bisa dikatakan sebagai suatu fantasi atau hanya suatu ekspetasi tentang lawan bicara kita. Secara sederhana dapat dikatakan bahwa konsep interpersonal menjadi bias, sedangkan konsep impersonal menjadi semakin kuat; ini berbeda ketika interaksi di ruang riil dimana baik konsep interpersonal maupun impersonal bisa terlihat dan bisa digambarkan dengan sangat baik, walaupun yang selalu kita tuju adalah pembentukan konsep interpersonal. 
Pada ruang virtual, konsep interpersonal, dalam arti pertemuan secara face to face yang bisa memperlihatkan selain mimik tetapi juga gesture bahkan kondisi lingkungan, akan sangat sulit digambarkan karena keterbatasan dan ketiadaan dari tampilan individu yang melakukan interaksi. Karenanya yang kita bisa lakukan terhadap lawan bicara kita hanyalah harapan bahwa lawan bicara kita melakukan seperti yang kita inginkan dan tidak melampaui batas yang kita harapkan. Seperti dikatakan oleh Judee Burgoon dalam West \& Turner (2009) yang menyatakan bahwa individu mempunyai ekspektasi mengenai perilaku (baik verbal maupun non-verbal) orang lain. Namun kalau Burgoon lebih menekankan pada konsep proksemik ( bagaimana manusia menggunakan ruang atau jarah untuk berkomunikasi), maka ketika kita berinteraksi di ruang virtual konsep proksemik yang merupakan buah pikiran Edward T Hall tidak mungkin karena konsepsi jarak yang menjadi asumsi utama dari konsep Proksemik tidak akan diketahui. Internet sebagai sebuah medium interaktif memediasi interaksi antar manusia dari sebuah 'titik' ke 'titik' lainnya melalui sebuah sistem yang sama. Sehingga dengan adanya penghubungan melalui sebuah 'server', maka jarak ditiadakan, waktu juga ditiadakan, karena kapan-pun dan dimana-pun kita akan melakukan interaksi bisa dilakukan selama dalam sebuah sistem yang sama. Lalu bagaimana membuat ekspektasi tersebut bisa dikelola dengan baik, terutama dalam interaksi di ruang virtual ?

Salah satu ekspektasi yang mungkin bisa dilakukan adalah melalui motif informatif dan komunikatif, akses, provisi, perdagangan, kerja, pendidikan dan seterusnya. Seperti dikatakakan oleh Moses A Bodourides dalam artikel mengenai New Directions of Internet Research, bahwa dalam jejaring sosial aktor mungkin merupakan manusia, seperti pengguna (users), komunikan, produser dan konsumen informasi, warga Negara (citizens), organisasi publik atau pasar dan lainnya atau bisa merupakan bukan manusia (non-human), seperti mesin komputer, data informasi, dokumen maupun hyper dokumen, sumber daya multimedia atau lainnya (http:// epp.eurostat.ec.europa.eu/portal/research_methodology/documents/03. pdf, diunduh 30 Maret 2010). Artinya Moses ingin mengatakan bahwa ketika berada di ruang virtual identitas diri menjadi suatu identitas yang tersembunyi, identitas yang bentuknya banyak (multiple) bahkan bisa dikatakan sebagai benda mati. Namun, pada artikel ini akan berfokus pada bentuk identitas dari manusia sebagai suatu diri.

Oleh karena itu dapat dikatakan bahwa ekspektasi antar sesama manusia dibatasi oleh keberadaan alat sebagai medium berkomunikasinya 
atau dapat dikatakan komunikasi konteks interpersonal bergeser menjadi komunikasi konteks interpersonal yang termediasi atau bahasa yang lazim dikenal sebagai interpersonal mediated communication. Karena sebuah ekspektasi terhadap manusia dibatasi artinya pengguna 'untuk sementara' mengetahui motif atau keinginan dari lawan bicaranya hanya melalui tampilan yang ada di layar komputer sebagai medium untuk berkomunikasi. Contoh sederhananya adalah pada medium jejaring sosial, maka harapan untuk melanjutkan komunikasi atau berhubungan dengan orang lain diketahui melalui profil yang ditampilkan, ruang memperbaharui status terus menerus (status updates) dari lawan bicara kita, hingga bisa terjadi pada ruang interaksi (chatting room).

Keterbatasan ekspektasi yang kita dapatkan dapat menghasilkan beberapa kemungkinan yang bisa digambarkan dalam bagan di bawah ini :

\section{Bagan 1}

Ekspektasi di Ruang Virtual dan Kelanjutan Komunikasi

\begin{tabular}{|c|l|l|}
\hline $\begin{array}{c}\text { Ekspektasi di ruang } \\
\text { virtual dan Kelanjutan } \\
\text { Komunikasi }\end{array}$ & $\begin{array}{l}\text { Kenal di Kehidupan Nyata (real } \\
\text { life), tapi tidak di kehidupan } \\
\text { virtual }\end{array}$ & $\begin{array}{c}\text { Tidak Kenal di Kehidupan } \\
\text { Nyata, tapi Kenal di } \\
\text { Kehidupan Virtual }\end{array}$ \\
\hline Ekspektasi Sesuai & $\begin{array}{l}\text { Komunikasi Berlanjut dan } \\
\text { hubungan bisa berproses ke } \\
\text { tahap selanjutnya }\end{array}$ & $\begin{array}{l}\text { Komunikasi berlanjut, tetapi } \\
\text { membutuhkan waktu untuk } \\
\text { mengetahui kebenaran dari } \\
\text { ekspektasi kita }\end{array}$ \\
\hline $\begin{array}{c}\text { Ekspektasi Tidak } \\
\text { Sesuai }\end{array}$ & $\begin{array}{l}\text { Bisa terus berlanjut apabila } \\
\text { terjadi penyesuaian atau ada } \\
\text { bagian-bagian dari kehidupan } \\
\text { di ruang riil yang bisa } \\
\text { dipertanggungjawabkan; tetapi } \\
\text { bisa tidak berlanjut, apabila } \\
\text { kehidupan di ruang riil tidak bisa } \\
\text { berubah }\end{array}$ & $\begin{array}{l}\text { Komunikasi tidak akan } \\
\text { berlanjut atau bisa dikatakan } \\
\text { bahwa hubungan tidak } \\
\text { berjalan ke tahap selanjutnya }\end{array}$ \\
\hline
\end{tabular}

Pada bagan ini memperlihatkan bahwa ekspektasi dan perkenalan di ruang riil sangat mempengaruhi proses suatu komunikasi dan perkembangan suatu hubungan, walaupun diantara mereka tidak saling kenal satu dengan lainnya. Artinya di ruang riil individu bisa mengetahui atau memutuskan secara langsung mengenai keberlanjutan suatu hubungan karena mereka bisa bertatapan secara langsung. Sedangkan di ruang virtual, perkenalan di ruang riil menjadi sangat penting, kalaupun individu tidak mengenal-pun, untuk kelangsungan suatu hubungan atau interaksi diperlukan pengelolaan kesan yang sifatnya termediasi. 
Ketika kita tidak mengenal individu lawan bicara kita di kehidupan riil, maka keputusan yang diambil menjadi dua hal yaitu pertama, tidak berlanjut apabila ekspektasi tidak sesuai dengan yang diinginkan, kedua, berlanjut apabila ekspektasi sesuai dengan yang diinginkan. Pada kedua kondisi ini ekspektasi bukan lagi disamakan dengan kehidupan di ruang riil, melainkan sangat tergantung dari kesan yang ditampilkan di layar. Semua kondisi yang terjadi memperlihatkan bahwa perkenalan di ruang riil lebih dominan untuk membuat suatu komunikasi terus berlanjut bahkan membuat peningkatan dalam sebuah hubungan. Sehingga dapat disimpulkan bahwa ketika interaksi terjadi di ruang virtual, maka yang dapat diketahui hanyalah pengelolaan kesan yang ditampilkan di wilayah depan dari interaksi.

\section{Pengelolaan Kesan di Ruang Virtual}

Karena dominasi mengenai diri lebih ditekankan pada ruang riil, maka identitas mengenai diri yang terjadi di ruang virtual lebih fokus pada usaha pengelolaan kesan terutama di panggung depan. Artinya di ruang virtual panggung depan fokus pada pengelolaan setting yang sama antara setiap pengguna dari facebook. Sedangkan yang membedakan antara seorang pengguna dengan pengguna lainnya adalah tampilan (performance) yang ditambahkan dan bisa dilakukan perbaikan (editing) oleh pengguna, misalnya tampilan profil, tampilan status, tampilan foto diri, bahkan juga referensi keanggotaan yang diikuti oleh pengguna. Artinya tampilan (performance) lebih merupakan suatu tampilan yang bisa dipersepsi langsung oleh khalayak dari tampilan awal yang terlihat langsung atau bisa dikatakan sebagai karakter virtual dari pengguna yang dapat dilihat langsung atau dinilai langsung oleh khalayak.

Sedangkan panggung belakang (back stage) merupakan wilayah yang memberikan gambaran bahwa individu dalam kondisi santai (relax) ketika berkomunikasi dengan orang lain. Seperti dikatakan oleh Sasan Zarghooni (2007:16), "jika gambaran diri adalah dalam kondisi relax atau santai ketika menulis pesan di dinding (wall) dari John tetapi tidak terjadi ketika menulis di dinding (wall) Anna, maka dapat dijelaskan bahwa kondisi ketika menulis di dinding John sebagai wilayah belakangnya"; dimana Goffman (1959:114) mengatakan bahwa kondisi rileks dari seseorang menandakan sebagai wilayah belakang dari interaksi yang terjadi. Bentuk lain dari panggung belakang adalah usaha pengiriman e-mail (electronic mail) antara dua orang. E-mail merupakan suatu bentuk pesan dimana terjadi konteks Komunikasi Antarpribadi (Interpersonal Communication), sehingga dapat 
dikatakan bahwa konteksnya adalah rahasia dan hanya diketahui oleh dua orang yang melakukan interaksi; atau dalam istilah Sandra Petrolio (West \& Turner, 2007:245) sebagai informasi rahasia (private information) yang batasnya kolektif (collective boundary) untuk kondisi ini; artinya informasi rahasia bukan lagi berbicara mengenai diri (self), namun lebih menekankan pada hubungan yang ada.

Namun E-mail-pun dapat bersifat massa, ketika e-mail yang berfungsi 'rahasia' dikirim ke banyak orang pada waktu yang bersamaan (artinya terjadi pengiriman pesan dari satu orang ke banyak orang - one to many), maka informasi bukan rahasia tetapi sudah bersifat publik. Sehingga untuk mengetahui wilayah belakang dari individu ketika ia mengalami suatu interaksi, caranya adalah tidak hanya mengamati perilaku maupun tindakan yang dilakukan, tetapi juga melakukan wawancara mengenai pesan yang ditulisnya. Artinya dapat dikatakan bahwa antara wilayah depan dengan wilayah belakang merupakan tempat dan kondisi yang berbeda.

Reese \& Nass (2002:99) mengatakan bahwa penciptaan sebuah karakter realitas virtual tidak tergantung pada gambaran riil. Kemudian mereka menambahkan bahwa membuat satu karakter cocok untuk semua kasus adalah sesuatu yang berat, salah satu caranya adalah menawarkan berbagai macam karakter yang bisa dipilih oleh penggunanya. Pernyataan Reese \& Nass memperlihatkan sebuah pemikiran kritis bahwa ketika manusia berinteraksi melalui internet, maka penciptaan sebuah karakter yang berbeda dengan segala bentuk interaksi yang terjadi akan sangat membantu manusia untuk terus berinteraksi dengan berbagai macam orang yang berbeda; artinya manusia mampu melakukan manipulasi mengenai karakter dirinya ketika mereka menggunakan internet dibandingkan ketika mereka melakukan tatap muka.

Reese \& Nass (2002:106) menambahkan pula bahwa "setiap usaha untuk melakukan manipulasi karakter dalam interaksi tatap muka sangat sulit, namun masalah tersebut dapat dipecahkan dengan pembentukan karakter yang dimediasi (mediated personality)". Kondisi berbeda ketika berinteraksi tentunya akan menciptakan suatu konstruksi berbeda tentang identitas diri untuk ditampilkan ke hadapan orang lain. ${ }^{3}$ Goffman dalam

3 Seperti dikatakan oleh Goffman bahwa tiap orang ketika berhadapan dengan kehidupan sehari-hari berusaha untuk merasakan kehidupan tersebut - artinya individu berusaha untuk mencoba untuk memahami tentang situasi yang dialaminya. Karena itu usaha untuk memahami situasi dibagi atas dua hal yaitu, strips dan frame. Strip dikatakan sebagai aktivitas sekuensial yang biasa dilakukannya, sedangakan frame (bingkai) merupakan penentuan bagaimana individu mengatur atau memahami perilaku mereka pada situasi tertentu. 
bukunya Frame Analysis menekankan bahwa orang-orang yang berada dalam situasi tertentu tidak menilai situasi tersebut, meskipun masyarakat mengatakannya". Artinya bahwa manusia mempunyai kekuasaan untuk melakukan konstruksi terhadap situasi interaksi yang dilakukannya dengan orang lain untuk menciptakan bentuk interaksi.

Konstruksi ketika melakukan interaksi merupakan suatu usaha untuk mengeskpresikan dirinya dan identitas orang lain, jadi ketika kita berinteraksi dengan sahabat kita dan kemudian wajah kita menampilkan kemarahan, maka konstruksi yang ditangkap sahabat kita adalah suatu 'yang harus dijauhi' - tentu saja tampilan berbeda juga akan diciptakan oleh sahabat kita. Berbeda kalau tampilannya adalah gembira, tampilan sahabat kita juga akan berbeda. Contoh inilah yang dikatakan Goffman (1959) sebagai gambaran diri (self-presentation).

Tampilan yang berbeda tentu saja tidak hanya dilakukan pada realitas nyata, tetapi juga ketika seorang individu melakukan interaksi pada realitas virtual yang hanya mengandalkan teks dan gambar. Baran (2006:328) mencoba untuk kritis terhadap persoalan identitas di ruang virtual dengan mengatakan bahwa pengguna situs-situs internet berusaha untuk mengalami kehidupan - baik hidupnya sendiri atau orang lain yang berbeda dengan pengalaman sebelumnya. Dengan mengalami suatu kehidupan bersama orang lain, Baran (2006) mengatakan, apakah kita dengan identitas riil yang kita miliki, berkata jujur dengan identitas tersebut ? Karena itu bisa dikatakan bahwa karakter personal kita, ketika berada di ruang virtual hanya eksis untuk ruang virtual, tidak seperti identitas kita di realitas sesungguhnya.

Artinya seperti yang dikatakan oleh Barran (2006) bahwa panggung depan (front stage) memegang peranan penting dalam usaha mengelola kesan. Misalnya saja seperti dikatakan oleh Zarghooni (2007:17) bahwa ketika seorang pengguna melakukan perbaikan, perubahan atau melakukan edit terhadap profil facebook-nya, maka ada dua kondisi yang muncul atau dua karakter dalam seorang individu, yaitu gambaran diri dilihat oleh orang lain pada profil pengguna (profil dirinya) dan diri, dalam arti yang sesungguhnya, sebagai pengguna yang berada di belakang layar komputer - atau bisa diilustrasikan dengan mengambil perkataan Descartes "Saya berpikir maka saya ada” (ini di ruang riil), maka di ruang virtual berubah menjadi "Dia berpikir, maka saya ada". 


\section{Kesimpulan}

Teknologi bukan hanya meningkatkan efektivitas dan efisiensi dalam melakukan aktivitas, tetapi juga membuat perubahan bentuk, sifat, dan konsep mengenai diri, interaksi, bahkan cara kita melakukan komunikasi. Dramaturgi yang dikemukakan oleh Erving Goffman secara sederhana adalah pengelolaan kesan dimana masing-masing pihak bisa memperlihatkan identitas untuk publik (front stage) - yang bisa kelihatan langsung baik melalui bentuk verbal (given) dan nonverbal (given off). Namun ketika berada di ruang virtual, maka interaksi dalam bentuk verbal di wilayah panggung depan tidak lagi terlihat secara langsung, tetapi sudah termediasi (mediated communication), karenanya kita tidak mengetahui perilaku maupun kondisi yang terjadi pada individu yang sedang berpikir tentang wilayah depan yang ditampilkan.

Begitu pula dengan ekspektasi untuk suatu hubungan, sangat tergantung pada pengelolaan kesan dimana motif menjadi suatu yang penting untuk ditampilkan, walaupun keputusan yang diambil bisa bersifat langsung (interaksi di ruang riil) ataupun tidak langsung atau termediasi (di ruang virtual). Karena itu dapat dikatakan bahwa ekspektasi berupa penggunaan konsep jarak menjadi tidak lagi dapat digunakan untuk menjelaskan tentang ekspektasi dalam berlanjutnya suatu hubungan atau interaksi.

Karena itu Goffman mengatakan bahwa mengelola kesan dianalogikan seperti kita mendayung di arus yang deras dengan menggunakan dayung berukuran kecil - artinya mengelola kesan adalah suatu aktivitas yang sedikit tapi akan menghasilkan dampak yang besar untuk kelanjutan suatu interaksi ataupun hubungan. Sehingga dapat dikatakan bahwa individu ketika berinteraksi di ruang virtual membutuhkan sedikit waktu untuk mengelola dan memikirkan tindakan yang harus ia lakukan, tapi kondisi ini tidak bisa dilakukan apabila kita berinteraksi di ruang riil - Goffman mengatakan ini sebagai sebuah permainan informasi.

\section{Daftar Pustaka}

Baldwin, John R., Perry, Stephen D \& Mary Anne Moffitt.2004. Communication Theories For Everyday Life. Person Education Inc. Boston.

Baran, Stanley J. 2006. Introduction to Mass Communication: Media Literacy and Culture, $4^{\text {th }}$ edition. McGraw Hill International Edition, NY

Berger, Peter L and Thomas Luckmann. 1966. The Sosial Construction of 
Reality A Treatise in the Sociology of Knowledge, New York, USA . Terjemahan Oleh Frans M Parera. 1990. Tafsir Sosial atas Kenyataan, LP3S, Jakarta

Bungin, Burhan. 2008. Konstruksi Sosial Media Massa : Kekuatan pengaruh media massa, iklan televisi, dan keputusan konsumen serta kritik terhadap Peter L Berger \& Thomas Luckmann. Kencana Prenada Media Group, Jakarta.

Goffman, Erving.1959. The Presentation of Self Everyday Life. Garden City, NY:Doubleday .1974. Frame Analysis : An Essay on the Organization of Experience. Northeastern University Press, USA

LittleJohn, Stephen. 2002. Theories of Human Communication, $5^{\text {th }}$ edition, Thomson Wadsworth.

LittleJohn, Stephen and Karen Foss. 2005. Theories of Human Communication, $8^{\text {th }}$ edition, Thomson Wadsworth.

Lister, Martin, Jon Dovey, et.al. 2003. New Media : A Critical Introduction. Routledge, NY

Mulyana, Deddy.2002. Metodologi Penelitian Kualitatif : Paradigma Baru Ilmu Komunikasi dan Ilmu Sosial Lainnya.PT Remaja Rosdakarya, Bandung

Perdue, William D. 1986. Sociological Theory : Explanation, Paradigm, and Ideology. Mayfield Publishing Company, Palo Alto, California, USA

Reeves, Byron \& Clifford Nass. 2002. The Media Equation: How People Treat Komputers, Television, and New Media Like Real People and Places. Cambridge University Press.

Turkle, Shirley. 1997. Life Beyond the Screen : identity in the age of internet. Simon \& Schuster, Inc, USA.

Turlow, Crispin., Lengel, Laura \& Alice Tomic. 2004. Computer Mediated Communication: Sosial Interaction and Internet. Sage Publikations, London

Trenholm, Sarah. 1991. Human Communication Theory, $2^{\text {nd }}$ Edition. Prentice Hall, Inc.of Oslo

Zarghooni, Sasan. 2007. A Study of Self-Presentation in Light of Facebook, Institute of Psychology, University of Oslo. 